\title{
Suppression of Multidrug Resistance by Migrastatin
}

\author{
Yasushi Takemoto, Etsu Tashiro, Masaya Imoto
}

Received: May 30, 2006 / Accepted: July 22, 2006

(C) Japan Antibiotics Research Association

\begin{abstract}
Migrastatin (MGS) is a Streptomyces metabolite that inhibits cancer cell migration. In this study, we found that MGS also enhanced the cytotoxicity of vinblastine, vincristine, and taxol in P-glycoprotein-overexpressing VJ300 cells and P388/VCR cells. Furthermore, MGS increased the intracellular concentration of labeled vinblastine, vincristine, and taxol in both VJ-300 cells and P388/VCR cells. P-glycoprotein was photolabeled with $\left[{ }^{3} \mathrm{H}\right]$ azidopine, but this photolabeling was significantly inhibited in the presence of MGS. These results indicated that MGS directly interacts with and inhibits P-glycoprotein, thereby sensitizing drug-resistant cells to anticancer drugs.
\end{abstract}

Keywords migrastatin, multi drug resistance, Pglycoprotein, anticancer drugs

\section{Introduction}

The development of drug resistance in the treatment of cancer continues to challenge oncologists. The hallmark of multidrug resistance is cross-resistance to multiple structurally unrelated compounds, such as the anthracyclines, taxanes, vinca alkaloids, and epipodophilotoxins $[1,2]$. The MDR-1 gene mediates one of the most extensively studied mechanisms of drug resistance [3]. The protein product of the MDR- 1 gene, P-glycoprotein (Pgp), is a $170-\mathrm{kDa}$ ATPdependent efflux pump located in the plasma membrane [4, 5]. Expression of this pump decreases intracellular drug concentration rendering tumor cells drug resistant. Because P-glycoprotein would be an important molecular target for cancer therapy, we searched for a compound that modulates

M. Imoto (Corresponding authors), Y. Takemoto, E. Tashiro: Department of Biosciences and Informatics, Faculty of Science and Technology, Keio University, 3-14-1 Hiyoshi, Kohoku-ku, Yokohama 223-8522, Japan, E-mail: imoto@bio.keio.ac.jp. its function in a library of natural products. In this paper, we report that migrastatin (MGS), which was originally isolated from Streptomyces sp. MK929-43F1 as an inhibitor of cancer cell migration [6 9], enhances the cytotoxicity of anticancer drugs in P-glycoprotein-overexpressing cells.

\section{Materials and Methods}

\section{Materials}

Migrastatin (MGS) was isolated from Streptomyces sp. as described previously [6]. Vinblastine, vincristine, and taxol were obtained from Wako Pure Chemical Industries, Ltd. (Tokyo, Japan). [G- $\left.{ }^{3} \mathrm{H}\right]$ vinblastine $(289 \mathrm{GBq} / \mathrm{mmol})$, [G- $\left.{ }^{3} \mathrm{H}\right]$ vincristine $(181 \mathrm{GBq} / \mathrm{mmol})$, and $\left[{ }^{3} \mathrm{H}\right]$ azidopine $(2.22 \mathrm{TBq} / \mathrm{mmol})$ were purchased from Amersham Japan Ltd (Tokyo, Japan). $\left.{ }^{3} \mathrm{H}\right]$ taxol $(740 \mathrm{GBq} / \mathrm{mmol})$ was purchased from American Radiolabeled Chemical, Inc (St. Louis, MO).

\section{Cell Culture}

Human epidermoid carcinoma $\mathrm{KB} / \mathrm{S}$ cells, vincristineresistant VJ-300 cells [10], mouse leukemia P388/S cells and vincristine-resistant P388/VCR cells [11] were kindly provided by Dr. M. Hayashi (Kitasato Institute). VJ-300 cells and P388/VCR cells were cultured in medium containing $10 \mathrm{ng} / \mathrm{ml}$ vincristine to maintain their drug resistance.

\section{MTT Cell Growth Assay}

The cells were seeded at $5 \times 10^{3}$ cells in $200 \mu \mathrm{l}$ of growth medium in 96-well plates. Drugs were added, and the cells were further incubated for 3 days. Ten microliters of $5 \mathrm{mg} / \mathrm{ml}$ 3-(4,5-dimethylthiazol-2-yl)-2,5-diphenyltetrazolium bromide (MTT) in phosphate-buffered saline (PBS) was added to each well, and the plate was incubated at $37^{\circ} \mathrm{C}$ for 4 hours. Then, $100 \mu \mathrm{l}$ of DMSO was added to cells. The 
amount of Formazan formed was measured at $570 \mathrm{~nm}$ using a MRP-A4 micro plate reader (Tosho).

\section{Measurement of Intracellular Concentration of Anti- cancer Drugs in Cancer Cells}

The cells were seeded at $5 \times 10^{4}$ cells in 24 -well plates and incubated at $37^{\circ} \mathrm{C}$ for 24 hours. Then, the cells were pretreated with or without MGS for 1 hour. Next, $7.4 \mathrm{KBq} / \mathrm{ml}(17 \mathrm{nM})\left[{ }^{3} \mathrm{H}\right]$ vinblastine, $7.4 \mathrm{KBq} / \mathrm{ml}(17 \mathrm{nM})$ $\left[{ }^{3} \mathrm{H}\right]$ vincristine, or $7.4 \mathrm{KBq} / \mathrm{ml}(17 \mathrm{nM})\left[{ }^{3} \mathrm{H}\right]$ taxol was added. After 2 hours, cells were washed with cold PBS and dissolved in $0.5 \mathrm{~N} \mathrm{NaOH}$, and the cell-associated radioactivity was measured with a liquid scintillation counter.

\section{Preparation and Photoaffinity Labeling of Plasma Membrane}

VJ-300 cells were homogenized in buffer A $(10 \mathrm{mM}$ Tris$\mathrm{HCl}$ buffer, $\mathrm{pH} 7.5,25 \mathrm{mM}$ sucrose, $0.2 \mathrm{mM} \mathrm{CaCl}_{2}$ and $1 \mathrm{mM}$ phenylmetylsulfonyl fluoride (PMSF)). The cell homogenate was diluted 4 fold with buffer B (10 mM Tris$\mathrm{HCl}, \mathrm{pH} 7.5$, and $25 \mathrm{mM}$ sucrose) and then centrifuged at $1000 \times g$ for 10 minutes. The supernatant was layered onto a $35 \%$ sucrose solution $(10 \mathrm{mM}$ Tris- $\mathrm{HCl}, \mathrm{pH} 7.5,35 \%$ sucrose, and $1 \mathrm{mM}$ EDTA) and centrifuged at $10,000 \times g$ for 30 minutes. The membrane fraction at the interface was collected, resuspended in buffer $\mathrm{B}$, and then centrifuged at $100,000 \times g$ for 60 minutes. The pellets (plasma membrane) were resuspended in buffer $\mathrm{C}(10 \mathrm{mM}$ Tris- $\mathrm{HCl}, \mathrm{pH} 7.5$, $250 \mathrm{mM}$ sucrose, and $1 \mathrm{mM}$ PMSF) and incubated with
$8.3 \mathrm{nM}\left[{ }^{3} \mathrm{H}\right]$ azidopine and drugs for 1 hour at $4^{\circ} \mathrm{C}$. The mixture was irradiated for 15 minutes at $4^{\circ} \mathrm{C}$ with an UV lamp $(312 \mathrm{~nm})$, and photolabeled membranes were analyzed by SDS-PAGE. The gel was fixed in a mixture of $30 \%$ acetic acid and $10 \%$ methanol, treated with Autoradiography Enhancer (PerkinElmer, Boston, MA) for 1 hour, dried, and then exposed for 2 weeks at $-80^{\circ} \mathrm{C}$ using Kodac XAR-5film.

\section{Results}

We examined the effect of MGS on the sensitivity of KB/S cells and their P-glycoprotein-overexpressing variant (VJ300) to vinblastine (VBL). As shown in Fig. 1A and Table 1 , VBL induced cell death with an $\mathrm{IC}_{50}$ of $2.0 \mathrm{ng} / \mathrm{ml}$ in $\mathrm{KB} / \mathrm{S}$ cells and of $216 \mathrm{ng} / \mathrm{ml}$ in VJ-300 cells. MGS did not show significant cytotoxicity up to $50 \mu \mathrm{g} / \mathrm{ml}$, however, it enhanced the sensitivity to VBL in VJ-300 cells in a dosedependent manner. Furthermore, MGS at $30 \mu \mathrm{g} / \mathrm{ml}$ enhanced the sensitivity to other anti-cancer drugs, such as vincristine (VCR) and taxol (TXL), in VJ-300 cells (Table 1). P-glycoprotein was also overexpressed in VCR-resistant mouse leukemia P388/VCR cells, and the sensitivity of P388/VCR to VBL was 21-fold lower than that of parental P388/S cells. However, the resistance to VBL in P388/VCR cells was also reduced by the addition of MGS in a dosedependent manner (Fig. 1B). These results indicated that MGS might be of potential use for the circumvention of MDR.
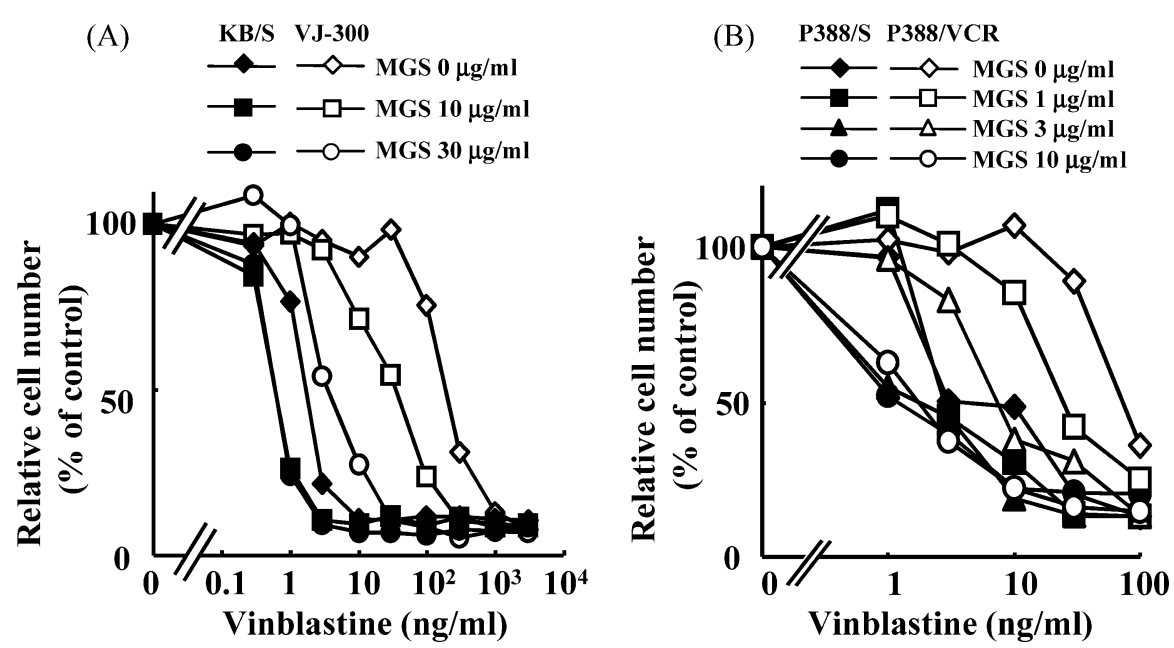

Fig. 1 Effect of MGS on sensitivity of drug-sensitive and drug-resistant tumor cells to vinblastine.

(A) KB/S cells or VJ-300 cells were incubated with VBL in the presence of various concentrations of MGS for 3 days. (B) P388/S or P388/NCR cells were incubated with VBL in the presence of various concentrations of MGS for 3 days. Cells were enumerated by MTT assay. The $100 \%$ values are the cell numbers with MGS alone in the absence of VBL. Values are means of two determinations. 
Table 1 Enhancement of the cytotoxicities of vinblastine, vincristine, and taxol by MGS

\begin{tabular}{lclc}
\hline \multirow{2}{*}{ Drugs } & MGS & \multicolumn{2}{c}{$\mathrm{IC}_{50}(\mathrm{ng} / \mathrm{ml})$} \\
\cline { 3 - 4 } & $(\mu \mathrm{g} / \mathrm{ml})$ & \multicolumn{1}{c}{$\mathrm{KB} / \mathrm{S}$} & $\mathrm{VJ}-300$ \\
\hline \multirow{2}{*}{ Vinblastine } & 0 & $2.0(1.0)^{\mathrm{a})}$ & $216(108)$ \\
& 10 & $0.72(0.4)$ & $40(20)$ \\
Vincristine & 30 & $0.71(0.4)$ & $4.1(2.1)$ \\
& 0 & $2.2(1.0)$ & $665(302)$ \\
Taxol & 30 & $0.69(0.3)$ & $17(11)$ \\
& 0 & $6.0(1.0)$ & $7680(1280)$ \\
& 30 & $4.6(0.8)$ & $151(25)$ \\
\hline
\end{tabular}

a) Numbers in parentheses, relative resistance.

Table 2 Enhancement of the intracellular concentrations of vinblastine, vincristine, and taxol by MGS

\begin{tabular}{lrcc}
\hline \multirow{2}{*}{ Drugs } & MGS & $\begin{array}{c}\text { Intracellular concentration } \\
(\% \text { of control })^{\text {a) }}\end{array}$ \\
\cline { 3 - 4 } & & KB/S & VJ-300 \\
\hline \multirow{2}{*}{ Vinblastine } & 0 & 100 & 17 \\
Vincristine & 30 & 219 & 81 \\
Taxol & 0 & 100 & 14 \\
& 30 & 188 & 71 \\
& 0 & 100 & 6 \\
\hline
\end{tabular}

a) The $100 \%$ values are for the intracellular concentration of drugs in $\mathrm{KB} / \mathrm{S}$ cells in the absence of MGS.

Since the intracellular concentration of anticancer drugs is decreased in P-glycoprotein-overexpressing tumor cells, the intracellular concentration of anticancer drugs in $\mathrm{KB} / \mathrm{S}$ and VJ-300 cells was measured in the presence or absence of MGS. As shown in Table 2, the intracellular concentration of $\left[{ }^{3} \mathrm{H}\right] \mathrm{VBL},\left[{ }^{3} \mathrm{H}\right] \mathrm{VCR}$, and $\left[{ }^{3} \mathrm{H}\right] \mathrm{TXL}$ in VJ-300 cells was $17 \%, 14 \%$ and $6 \%$ of that in $\mathrm{KB} / \mathrm{S}$ cells, respectively. A significant increase in intracellular concentration of $\left[{ }^{3} \mathrm{H}\right] \mathrm{VBL},\left[{ }^{3} \mathrm{H}\right] \mathrm{VCR}$, and $\left[{ }^{3} \mathrm{H}\right] \mathrm{TXL}$ was observed following the addition of $30 \mu \mathrm{g} / \mathrm{ml}$ of MGS in VJ-300 cells. MGS also increased the intracellular concentration of $\left[{ }^{3} \mathrm{H}\right] \mathrm{VBL}$ in $\mathrm{P} 388 / \mathrm{VCR}$ cells (Fig. 2). These results indicated that the potentiation of the cytotoxicity of anticancer drugs by MGS in P-glycoproteinoverexpressing cells was due to an enhancement of the intracellular concentration of the drugs by MGS.

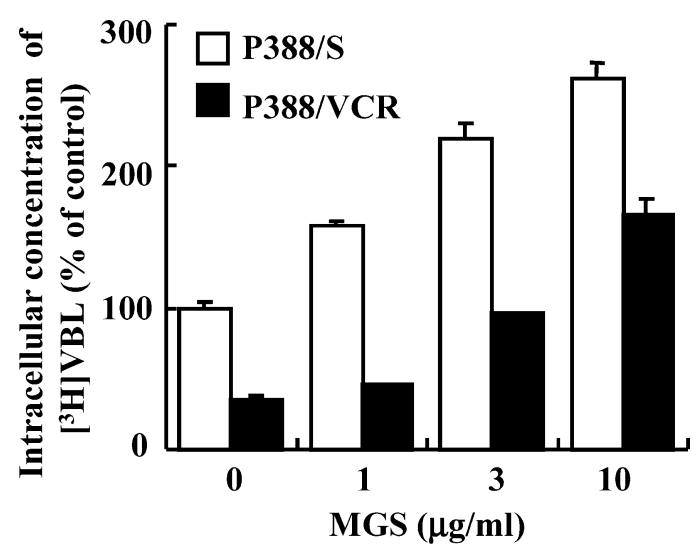

Fig. 2 Enhancement of intracellular concentration of vinblastine by MGS in P388/NCR cells.

P388/S or P388NCR cells were pretreated with MGS for 1 hour and treated with $\left[{ }^{3} \mathrm{H}\right] \mathrm{VBL}$ for 2 hours. Cells were washed and resolved in $0.5 \mathrm{~N} \mathrm{NaOH}$, and measured for radioactivity. Values are means of four independent determinations; bars, SD. The 100\% values are for the intracellular concentration of $\left[{ }^{3} \mathrm{H}\right] \mathrm{VBL}$ in P388/S cells in the absence of MGS.

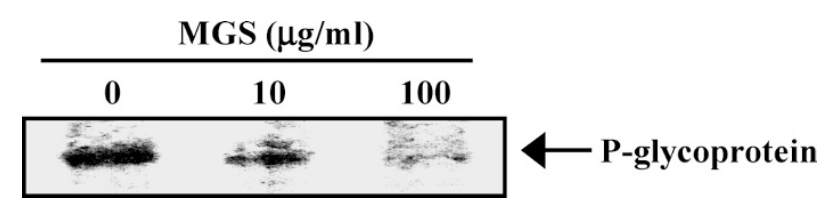

Fig. 3 Effect of MGS on photolabeling of P-glycoprotein with ${ }^{3}$ H]azidopine.

The membrane vesicles (150 mg of protein) of VJ-300 cells were photolabeled with $8.3 \mathrm{nM}$ of $\left[{ }^{3} \mathrm{H}\right]$ azidopine for 15 minutes at $4^{\circ} \mathrm{C}$ in the presence of the indicated concentrations of MGS, and analyzed by SDS-PAGE and Fluorography.

It was reported that P-glycoprotein is photolabeled with azidopine, and this labeling is inhibited in the presence of compounds that are substrates of P-glycoprotein $[12,13]$. Thus, we examined whether MGS inhibited the photolabeling of P-glycoprotein with $\left[{ }^{3} \mathrm{H}\right]$ azidopine. As shown in Fig. 3, MGS inhibited the binding of $\left[{ }^{3} \mathrm{H}\right]$ azidopine to Pglycoprotein in VJ-300 cells in a dose-dependent manner. Hence, the reversing effect of MGS on MDR tumor cells is due, at least in part, to its direct interaction with $\mathrm{P}$ glycoprotein.

\section{Discussion}

In the present study, we demonstrated that MGS overcame the resistance to anticancer drugs in P-glycoprotein- 
overexpressing tumor cells. Several studies have suggested that direct interaction with cytotoxic drug-binding sites on P-glycoprotein was involved in the mechanism of reversing MDR with chemosensitizers. MGS inhibited the binding of $\left[{ }^{3} \mathrm{H}\right]$ azidopine to P-glycoprotein, therefore, MGS would directly inhibit the function of P-glycoprotein. There are several sites on P-glycoprotein for drug-binding and transport that interact in a cooperative manner [14]. R site preferentially recognizes rhodamine-123, doxorubicin, and daunorubicin. $\mathrm{H}$ site preferentially recognizes Hoechst 33342 and colchicine. VBL, actinomycin D, and etoposide interact equally with both sites [14]. Inhibition of the photolabeling by VBL suggests that azidopine interacts with P-glycoprotein at the same site as VBL [15]. Our finding that MGS inhibited the photolabeling with azidopine indicates MGS directly interacts at the azidopineand VBL-binding site of P-glycoprotein.

Because MGS is an effective inhibitor of P-glycoprotein, the results of more advanced in vivo tests will be pivotal in contemplating further development of MGS as a clinically useful pharmaceutical agent.

Acknowledgments This study was supported by the project on "Molecules, Supra Molecules and Suprs-Structured Materials" from the Ministry of Education, Culture, Sports, Science and Technology, Japan.

\section{References}

1. Ueda K, Cornwell MM, Gottesman MM, Pastan I, Roninson IB, Ling V, Riordan JR. The mdr1 gene, responsible for multidrug-resistance, codes for P-glycoprotein. Biochem Biophys Res Commun 141: 956-962 (1986)

2. Ueda K, Cardarelli C, Gottesman MM, Pastan. Expression of a full-length cDNA for the human "MDR1" gene confers resistance to colchicine, doxorubicin, and vinblastine. Proc Natl Acad Sci USA 84: 3004-3008 (1987)

3. Tsuruo T. Mechanisms of multidrug resistance and implications for therapy. Jpn J Cancer Res 79: 285-296 (1988)

4. Sugimoto Y, Tsuruo T. DNA-mediated transfer and cloning of a human multidrug-resistant gene of adriamycin-resistant myelogenous leukemia K562. Cancer Res 47: 2620-2625
(1987)

5. Hamada H, Tsuruo T. Functional role for the 170- to 180$\mathrm{kDa}$ glycoprotein specific to drug-resistant tumor cells as revealed by monoclonal antibodies. Proc Natl Acad Sci USA 83: 7785-7789 (1986)

6. Nakae K, Yoshimoto Y, Sawa T, Homma Y, Hamada M, Takeuchi T, Imoto M. Migrastatin, a new inhibitor of tumor cell migration from Streptomyces sp. MK929-43F1. Taxonomy, fermentation, isolation and biological activities. J Antibiot 53: 1130-1136 (2000)

7. Nakae K, Yoshimoto Y, Ueda M, Sawa T, Takahashi Y, Naganawa H, Takeuchi T, Imoto M. Migrastatin, a novel 14membered lactone from Streptomyces sp. MK929-43F1. J Antibiot 53: 1228-1230 (2000)

8. Takemoto Y, Nakae K, Kawatani M, Takahashi Y, Naganawa H, Imoto M. Migrastatin, a novel 14-membered ring macrolide, inhibits anchorage-independent growth of human small cell lung carcinoma Ms-1 cells. J Antibiot 54: 1104-1107 (2001)

9. Nakamura H, Takahashi Y, Naganawa H, Nakae K, Imoto M, Shiro M, Matsumura K, Watanabe H, Kitahara T. Absolute configuration of migrastatin, a novel 14-membered ring macrolide. J Antibiot 55: 442-444 (2002)

10. Kohno K, Kikuchi J, Sato S, Takano H, Saburi Y, Asoh K, Kuwano M. Vincristine-resistant human cancer KB cell line and increased expression of multidrug-resistance gene. Jpn J Cancer Res 79: 1238-1246 (1988)

11. Tsuruo T, Iida H, Tsukagoshi S, Sakurai Y. Overcoming of vincristine resistance in $\mathrm{P} 388$ leukemia in vivo and in vitro through enhanced cytotoxicity of vincristine and vinblastine by verapamil. Cancer Res 41: 1967-1972 (1981)

12. Safa AR, Glover CJ, Sewell JL, Meyers MB, Biedler JL, Felsted RL. Identification of the multidrug resistance-related membrane glycoprotein as an acceptor for calcium channel blockers. J Biol Chem 262: 7884-7888 (1987)

13. Yang C-PH, Mellado W, Horwitz SB. Azidopine photoaffinity labeling of multidrug resistance-associated glycoprotein. Biochem Pharmacol 37: 1417-1421 (1988)

14. Shapiro AB, Ling V. Positively cooperative sites for drug transport by P-glycoprotein with distinct drug specificities. Eur J Biochem 250: 130-137 (1997)

15. Bruggemann EP, Currier SJ, Gottesman MM, Pastan I. Characterization of the azidopine and vinblastine binding site of P-glycoprotein. J Biol Chem 267: 21020-21026 (1992) 